ARTUR MODLIŃSKI

ORCID: 0000-0002-5734-7975

Uniwersytet Łódzki

\title{
Decyzje konsumenckie w dobie rewolucji cyfrowej i sztucznej inteligencji — przegląd trendów
}

DOI: 10.19195/2083-7763.9.14

\section{Wstęp}

Dynamiczny rozwój sztucznej inteligencji oraz nowych technologii zmienia przestrzeń, w której funkcjonuje i podejmuje decyzje współczesny konsument. Charakterystyczny jest powszechny dostęp do informacji oraz możliwość wymiany opinii z innymi uczestnikami rynku, dzięki którym nabywca może, jeśli tylko chce, precyzyjniej zaplanować i dokonać zakupu. Zgodnie z trendem wzmacniania pozycji konsumenta ( $\mathrm{z}$ ang. consumer empowerment) zdanie nabywcy zyskuje na znaczeniu, a jego ignorowanie przez firmę może doprowadzić do konfliktu z szerszą grupą odbiorców ${ }^{1}$. Dzięki mediom społecznościowym i efektowi usieciowienia konsumenci tworzą coraz spójniejsze i wzajemnie uzupełniające się grupy, które dostarczają sobie nawzajem informacji potrzebnych do podjęcia decyzji, pozwalając uchronić potencjalnych nabywców przed oszustwami i rozczarowaniem. O ile jeszcze dekadę temu nabywcy pytali o radę odnośnie do zakupów głównie najbliższe otoczenie (rodzinę, znajomych), o tyle obecnie na ich zachowania coraz częściej wpływają osoby nieznane, które kreują się na ekspertów i udostępniają swoje opinie własnymi kanałami w mediach społecznościowych oraz na blogach.

Warto zauważyć, że dostęp do aplikacji mobilnych umożliwia porównywanie produktów i usług pod względem ważnych dla konsumentów kryteriów (cena, jakość, dostępność itp.) oraz opinii osób, którzy mieli okazję przetestować daną

${ }^{1}$ A. Modliński, Miękkie i agresywne formy sprzeciwu konsumentów wobec niepożadanych zachowań rynkowych, [w:] Innowacyjne działania $w$ obszarze zarządzania i marketingu, red. A.A. Wadlewski, A. Modliński, Łódź 2015, s. 88-89. 
ofertę. W związku z rozwojem firm kurierskich coraz powszechniejsze staje się dokonanie zamówienia przez internet (także po sprawdzeniu oferty w sklepie stacjonarnym) z możliwością zwrotu towaru bez wychodzenia z domu. Sami konsumenci, zgodnie z przewidywaniami Alvina Tofflera, stają się jednocześnie producentami, którzy coraz częściej angażują się w tworzenie bądź ulepszanie produktów i usług 2 . Trend otwartej współpracy użytkowników internetu oraz rozwój sektora usługowego doprowadziły do powstania licznych inicjatyw mających u swych podstaw ideę "dzielenia się", co w literaturze zaczęto określać mianem „ekonomii współdzielenia”. Powstająca na tej podstawie „wspólnotowość” oznacza obecnie nie tyle szeroko rozumianą kolektywność w użytkowaniu produktów, ile solidarność w wyrażaniu opinii i służenie innym radą konsumencką. Jej przykłady zostaną przedstawione w dalszej części opracowania.

\section{Konsumpcja w dobie nowych technologii}

Rozwój internetu oraz nowych technologii przyczynił się do powstania narzędzi, którymi może posługiwać się współczesny konsument w celu zoptymalizowania podejmowanych przez siebie decyzji zakupowych. W związku z tak zwaną rewolucją cyfrową można wyróżnić cztery trendy mające wpływ na kształt procesu decyzyjnego nabywców w drugiej dekadzie XXI wieku. Należą do nich:

- sukcesywny wzrost liczby szeroko rozumianych aplikacji, które pozwalają nabywcy na wyszukiwanie i porównywanie z sobą ofert różnych sklepów mających stronę internetową;

- tworzenie oprogramowania, które ma na celu ułatwienie nabywcy nawiązanie kontaktu z przedsiębiorstwem oraz rozwój systemów rekomendacyjnych pozwalających dopasować ofertę do profilu konsumenta;

- fora internetowe oraz grupy tematyczne w mediach społecznościowych, gdzie nabywca może zapoznać się z opiniami innych konsumentów (aktualnymi oraz potencjalnymi) oraz nawiązać z nimi konwersację;

- rozwój sztucznej inteligencji oraz marketingu rzeczy, który umożliwia planowanie zakupów just-in-time (na bieżąco), dostarczenie ich pod wskazany adres oraz dokonanie płatności przez internet.

\subsection{Aplikacje mobilne}

Wraz z coraz powszechniejszym dostępem do internetu i urządzeń mobilnych systematycznie wzrasta liczba konsumentów korzystających $\mathrm{z}$ aplikacji w procesie podejmowania decyzji zakupowych. Aplikacja dla klientów to program kompu-

2 A. Toffler, The Third Wave, New York 1980, s. 11.

3 T. Puschmann, R. Alt, Sharing economy, „Business \& Information Systems Engineering” 58, 2016, nr 1, s. 93-94. 
terowy, który działając w tabletach czy smartfonach, umożliwia dostęp do treści mającej pomóc im dokonać wyboru ${ }^{4}$. Należą do nich zarówno strony internetowe konkretnych producentów/usługodawców, jak i platformy tworzone przez samych nabywców, związki konsumenckie czy start-upy. Urządzenia mobilne są coraz bardziej funkcjonalne, zapewniając konsumentowi dostęp do informacji o produkcie/usłudze $\mathrm{w}$ dowolnym miejscu, w którym możliwe jest połączenie się $\mathrm{z}$ internetem ${ }^{5}$. Nabywca zainteresowany konkretnym produktem, oglądając go w sklepie stacjonarnym, może sprawdzić warunki analogicznej oferty u konkurenta oraz dokonać zakupu przez internet, jeśli oferta jest atrakcyjniejsza (na przykład ma niższą cenę, dodawane są prezenty). Aplikacje przeznaczone dla konsumentów można podzielić na dwie kategorie:

- służące do porównywania wybranych cech oferty/produktu lub usługi,

— zwiększające wiedzę konsumentów na temat produktu/usługi bądź praktyk biznesowych samego oferenta.

W wypadku pierwszej grupy można zauważyć przewagę aplikacji służących porównywaniu cen oraz jakości produktów i usług, jak Ceneo, Mobit Scanner oraz Opineo.pl. Dzięki Ceneo.pl potencjalny konsument po wpisaniu nazwy produktu może sprawdzić i porównać jego ceny w różnych sklepach. Dodatkowo uwzględniona została cena przesyłki oraz hiperłącze, które pozwala nabywcy przejść bezpośrednio do wybranego sklepu oraz dokonać zakupu przez internet. Dla niezdecydowanych przewidziano podstronę z opiniami wcześniejszych nabywców. Bardziej zaawansowaną aplikacją jest Mobit Scanner, który zainstalowany w smartfonie umożliwia skanowanie kodów kreskowych i uzyskanie informacji o tym samym produkcie $\mathrm{w}$ innym sklepach. Oprócz porównania cen nabywca otrzymuje również informację, czy interesujący go produkt został uznany za niebezpieczny bądź zagrażający zdrowiu oraz jak oceniają go dotychczasowi użytkownicy. Z kolei dzięki Opineo.pl nabywcy mogą sprawdzić pozycję danego sklepu, produktu bądź firmy w rankingu konsumentów według określonej kategorii. Każde z powyższych oceniane jest na pięciostopniowej skali, a nabywcy mogą dodawać swoje komentarze w dłuższej formie pisemnej. Najlepsze produkty i sklepy otrzymują corocznie laur jakości, który ma świadczyć o ich najwyższej jakości i aprobacie użytkowników.

Druga kategoria aplikacji, u której podstaw leży chęć poszerzenia wiedzy konsumenta na temat oferty, zawiera bardziej zróżnicowane tematycznie pozycje. Pod względem ilościowym na polskim rynku przeważają narzędzia umożliwiające nabywcom uzyskanie wiedzy na temat:

${ }^{4}$ A.J.G. Silvius, C.M. Silvius, Exploring functionality of mobile applications for project management, „Procedia Computer Science” 64, 2015, s. 344.

${ }^{5}$ A. Holzer, J. Ondrus, Mobile application market: A developer's perspective, „Telematics and Informatics" 28, 2011, s. 22-23. 
- wpływu danego produktu na ich zdrowie;

- wykorzystania zwierząt do badań laboratoryjnych;

- (nie)etycznych praktyk oferentów względem swych pracowników.

Do sprawdzenia wpływu produktu na zdrowie służą takie aplikacje, jak E-numery, Tetra Pak, E-Składniki czy Czytamy etykiety. Pozwalają one zidentyfikować substancje zawarte $\mathrm{w}$ analizowanych produktach spożywczych oraz określić ich wpływ na zdrowie. Tego typu pomoc dla potencjalnych konsumentów jest odpowiedzią na nieetyczne praktyki polegające na maskowaniu konserwantów czy manipulowaniu informacjami przez nieuczciwych oferentów pozorujących sprzedaż zdrowego, ekologicznego produktu przez zmianę opakowania bądź nazwy, co w literaturze opisywane jest jako green- i leanwahing ${ }^{6}$.

W drugim przypadku nabywcy mają możliwość skorzystania z aplikacji Bunny Free, Cosmetic Free czy Choose Cruelty Free. Każda z nich pozwala uzyskać informację, czy dana marka lub przedsiębiorstwo testuje swoje produkty na zwierzętach. Nabywca może wpisać nazwę oferenta bądź zeskanować kod na opakowaniu w sklepie stacjonarnym. Konsumenci, dla których istotne są przestrzeganie praw pracowniczych i szeroko rozumiana filozofia sprawiedliwego handlu (fair trade), mogą skorzystać z aplikacji Good On You. Ocena poszczególnych oferentów opiera się na warunkach zatrudniania pracowników oraz wpływie firmy na środowisko naturalne. Każdej marce bądź przedsiębiorstwu przypisana zostaje ocena na pięciostopniowej skali oraz pozycja w ogólnym rankingu zaufania.

Dostęp do aplikacji mobilnych pozwala konsumentom zwiększyć wiedzę na temat oferty i oferenta oraz wybrać produkty, które najbardziej odpowiadają ich sposobowi postrzegania świata. Negatywne opinie innych użytkowników, zbyt wygórowana cena czy nieetyczne praktyki mogą skutecznie zniechęcić potencjalnych nabywców i narazić przedsiębiorstwo na utratę pozycji rynkowej względem konkurentów.

\subsection{Chatboty i systemy rekomendacyjne}

Wobec sukcesywnie rosnącej aktywności konsumentów w internecie można zauważyć dwa trendy, które mają pomóc im zbliżyć się do konkretnej marki oraz znaleźć ofertę najbardziej odpowiadającej ich gustom. Należą do nich tworzone przez oferentów chatboty oraz systemy rekomendacyjne.

Chatboty to programy opierające się na sztucznej inteligencji, które umożliwiają konsumentom nawiązanie rozmowy przypominającej konwersację z człowiekiem ${ }^{7}$. Dzięki stworzonemu oprogramowaniu oraz uczeniu się w praktyce,

${ }^{6}$ A. Karnani, B. McFerran, A. Mukhopadhyay, Leanwashing: A Hidden Factor in the Obesity Crisis, „California Management Review” 56, 2014, nr 4, s. 15-17.

${ }^{7}$ K. Brennan, The managed teacher, emotional labour, education, and technology, „Educational Insights" 10, 2006, nr 2, s. 61. 
odpowiadając na pytania potencjalnych nabywców związane z ofertą, historią firmy czy przyjmując reklamacje, mogą zostać nierozpoznane jako programy komputerowe. Chatboty stały się rozwiązaniem dla przedsiębiorstw, które starają się sprostać zainteresowaniu konsumentów i nawiązać z nimi relacje. Pozwoliły przy tym na redukcje kosztów związanych z utrzymaniem infolinii oraz zatrudnianiem w niej kolejnych pracowników ${ }^{8}$. Nabywca produktu bądź usługobiorca może skontaktować się z danym oferentem o dowolnej porze, ponieważ chatboty - w przeciwieństwie do osób zajmujących się obsługą klienta — są aktywne przez całą dobę.

Drugi ze wspomnianych trendów - systemy rekomendacyjne - działa na zasadzie filtrowania ofert na podstawie gustów konsumentów. Z tego typu rozwiązań korzystają takie marki, jak Amazon, Netflix czy Spotify. Uwzględniając wcześniejsze wybory oraz aktywność nabywców, proponują oferty, które są najbardziej zbliżone do ich profilu zakupowego. Szacuje się, że systemy rekomendacyjne są odpowiedzialne nawet za jedną trzecią przychodów przedsiębiorstw, które zdecydowały się na ich zastosowanie ${ }^{9}$. Dla samych konsumentów z kolei oznaczają one łatwiejszy dostęp do interesujących ich ofert, krótszy czas poświęcony na ich wyszukiwanie oraz większą satysfakcję pozakupową ${ }^{10}$.

Warto zauważyć, że nowe technologie tylko pozornie pozwalają przedsiębiorstwom na pełną automatyzację. O ile chatboty pozwoliły na zmniejszenie kosztów związanych z obsługą klienta, o tyle sami nabywcy nadal podkreślają większą chęć kontaktu z żywą osobą aniżeli z programem komputerowym. Nieumiejętne naśladowanie przedstawicieli firmy przez chatboty może wywoływać w odbiorcach poczucie bycia ignorowanymi. Kluczowe jest zatem ciągłe ulepszanie tworzonych programów i systematyczne sprawdzanie reakcji samych konsumentów na tego rodzaju konwersacje. Podobnych działań wymagają systemy rekomendacyjne. Aby spełniały one swoje zadanie, należy nie tylko stworzyć skuteczne algorytmy, lecz także systematycznie je aktualizować i sprawdzać opinie konsumentów na temat ich trafności. Jest to szczególnie ważne, gdy użytkownicy oprócz opierania się na rekomendacjach i kontaktach z przedsiębiorstwem szukają rady także u innych nabywców poprzez fora internetowe i media społecznościowe.

\subsection{Fora wymiany i liderzy opinii}

Fora wymiany informacji to strony, na których konsumenci dzielą się doświadczeniami na temat używanych produktów i usług. Zyskują one szczególne znaczenie

${ }^{8}$ M. van Eeuwen, Mobile conversational commerce: Messenger chatbots as the next interface between businesses and consumer, s. 3-5, https://essay.utwente.nl/71706/1/van\%20Eeuwen_MA_BMS. pdf (dostęp: 27.02.2019).

${ }^{9}$ K. Keller, Nieuniknione. Jak inteligentne technologie zmienia nasza przyszłość, przeł. P. Cypriański, Warszawa 2017, s. 239.

10 Ibidem, s. 240. 
w przypadku zakupów o tak zwanym długookresowym efekcie oddziaływania. Do tej kategorii można zaliczyć na przykład urządzenia RTV/AGD oraz samochody. Na takich forach, jak Guruagd.pl, Wizaz.pl, Forumsamochodowe.pl czy Kafeteria. pl nabywcy mogą nawiązać bezpośredni kontakt z aktualnymi użytkownikami produktów, które zamierzają kupić, oraz zadawać pytania, czego nie przewidziano w przypadku większości aplikacji mobilnych. Część wskazanych forów przewiduje hierarchizację zarejestrowanych użytkowników ze względu na ich aktywność oraz trafność udzielanych rad. Tym samym konsument szukający opinii uzyskuje informacje, który z użytkowników jest bardziej lub mniej wiarygodny. Istotnymi ograniczeniami forów internetowych są się jednak ich anonimowość, która może skutecznie obniżać poziom zaufania użytkowników, oraz nieprzestrzeganie zasad fachowej dyskusji, opartej na kulturze słowa i wzajemnym szacunku.

Inną metodą zwiększenia wiedzy na temat wybranych produktów i usług są tak zwane grupy w mediach społecznościowych. Dzięki nim użytkownicy nawiązują kontakt $\mathrm{z}$ aktualnymi nabywcami, mogą zadawać pytania oraz na bieżąco śledzić rozwój dyskusji. W porównaniu z wcześniej opisanymi forami internetowymi media społecznościowe gwarantują większy stopień spersonalizowania. Każdy z użytkowników może zapoznać się z prywatnym profilem innego członka grupy, prześledzić jego zainteresowania oraz grupę znajomych. Oprócz dyskusji publicznej użytkownicy mają możliwość prowadzenia rozmowy prywatnej.

Istotną rolę w mediach społecznościowych odgrywają także tak zwani niezależni eksperci. Są to osoby, które aspirują do recenzowania produktów bądź usług w wybranej kategorii. Poprzez założenie otwartego profilu na Facebooku, Twiterze, Instagramie czy YouTubie i testowanie produktu oraz dokumentowanie tego procesu w postaci zdjęć i filmów zachęcają oni pozostałych użytkowników do śledzenia ich aktywności. Wraz z sukcesywnym powiększaniem swojego grona odbiorców oraz interakcjami, na przykład poprzez komentarze, zyskują oni społeczną aprobatę, stając się liderami opinii. Taka pozycja zwiększa finansową wartość prowadzonego przez nich profilu i zachęca reklamodawców do współpracy.

Oprócz mediów społecznościowych liderzy opinii aktywizują się również na prowadzonych przez siebie blogach i vlogach. Istotną różnicą pomiędzy nimi jest sposób udostępniania informacji - o ile na blogu dominuje tekst, o tyle w wypadku vloga jest to materiał wideo ${ }^{11}$. W obu publikujący opiera się na bardziej spersonalizowanej domenie, która w przypadku rosnącej liczby odwiedzin może zostać korzystniej sprzedana niż profil w mediach społecznościowych. Prowadzenie bloga/vloga pozwala na większą niezależność twórcy treści, jako że nie jest on zobligowany do przestrzegania szczegółowego regulaminu, którego akceptacja jest koniecznością w przypadku publikowania w mediach społecznościowych.

${ }^{11}$ D. Sanchez-Cortes et al., In the mood for vlog: Multimodal inference in conversational social video, „ACM Transactions on Interactive Intelligent Systems (TiiS) - Special Issue on Behavior Understanding for Arts and Entertainment (part 1 of 2)" 5, 2015, nr 2, s. 9:3. 
Konsumenci śledzący blogi/vlogi mają nadzieję na uzyskanie bardziej rzetelnych i wiarygodnych informacji aniżeli te, które przekazywane im są bezpośrednio przed producentów w reklamach ${ }^{12}$.

Fora internetowe, profile w mediach społecznościowych oraz blogi i vlogi nie są jednak obecnie całkowicie niezależnymi i wiarygodnymi źródłami informacji konsumenckiej. Zauważa się, że część producentów i usługodawców tworzy fikcyjne konta, aby zachęcać potencjalnych nabywców do skorzystania $\mathrm{z}$ ich oferty. Tego typu zjawisko ma miejsce nie tylko pod postacią aktywności fikcyjnych komentujących, lecz także poprzez budowanie całych kanałów (na przykład blogów finansowanych przez konkretną markę). Innym nieetycznym zachowaniem przedsiębiorstw może być zachęcanie liderów opinii do prezentowania ich oferty w korzystny sposób w zamian za ustaloną gratyfikację.

\subsection{Planowanie ze sztuczną inteligencją}

Dzięki rozwojowi nowych technologii współczesny konsument zyskał wiele rozwiązań w zakresie planowania, które mają na celu zoptymalizowanie jego zakupów oraz uniknięcie marnotrawstwa zasobów (czasu i pieniędzy). Osią rozwoju w tym obszarze stała się sztuczna inteligencja, a w szczególności jej zastosowanie w urządzeniach codziennego użytku. Na wskazanie zasługuje w szczególności internet rzeczy (Internet of Things). O ile początki sztucznej inteligencji sięgają lat 50. XX wieku (konferencja w Dartmouth), o tyle jej szersze zastosowanie komercyjne można zaobserwować dopiero od początku pierwszej dekady XXI wieku. Jej celem jest umożliwienie uczenia się programom tworzonym przez człowieka ${ }^{13}$. Dziś sztuczna inteligencja znajduje zastosowanie $\mathrm{w}$ aplikacjach, które zbierając dane o użytkowniku, są w stanie stworzyć jego profil, określić gusta i zainteresowania, a tym samym przewidywać i sugerować rozwiązania konkretnych problemów. Jej wykorzystanie w takich urządzeniach, jak lodówka czy pralka, oraz połączenie ich ze smartfonem umożliwia konsumentom przewidywanie, jakie produkty wkrótce się skończą, oraz kiedy i gdzie powinni je kupić.

Dzięki analizie dotychczasowych zakupów aplikacje opierające się na sztucznej inteligencji mogą proponować swoim użytkownikom nowości odpowiadające jego profilowi bądź zasugerować dokonanie zakupu w sklepie, który jest bardziej korzystny cenowo. Sztuczna inteligencja nadal pozostaje jednak rozwiązaniem wspierającym konsumenta, a nie podejmującym za niego decyzje. Korzystający z niej zgadza się na zbieranie o sobie danych i autoprofilowanie ${ }^{14}$. Część nabywców

12 C. Obermiller, E.R. Spangenberg, Development of a scale to measure consumer skepticism toward advertising, „Journal of Consumer Psychology” 7, 1998, nr 2, s. 159-160.

${ }^{13}$ R. Akerkar, Artificial Intelligence for Business, Harvard 2018, s. 3-4.

14 J. Konota, Nieuświadomiona rewolucja cyfrowa. Czy powinniśmy się bać internetu rzeczy?, „Harvard Business Review Polska”, https://www.hbrp.pl/b/nieuswiadomiona-rewolucja-cyfrowa-czy-powinnismy-sie-bac-internetu-rzeczy/NINMx88p (dostęp: 29.10.2018). 
wyraża się sceptycznie wobec takich praktyk, podkreślając swoje obawy o bezpieczeństwo przechowywanych informacji oraz możliwość manipulowania nimi przez hakerów czy złośliwe oprogramowanie. Mimo to sztuczna inteligencja systematycznie zyskuje na popularności, stając się istotnym trendem kształtującym sposób podejmowania decyzji przez współczesnych konsumentów.

\section{Zakończenie}

Nowe technologie wpływają na sposób podejmowania decyzji przez współczesnych konsumentów. Z jednej strony dynamiczny rozwój i powszechny dostęp do internetu sprawił, że nabywcy zyskali możliwość odnalezienia konkretnej informacji na temat interesującej ich oferty, z drugiej zaś to samo zjawisko doprowadziło do tak zwanego zalania informacjami ( $\mathrm{z}$ ang. infoglut), z których wiarygodnością nabywcy muszą się sukcesywnie mierzyć. Jest to proces o tyle złożony, że część przedsiębiorstw decyduje się na tworzenie fałszywej treści, zakładanie kont wymyślonym przez siebie użytkownikom i symulowanie aktualnych konsumentów, pozornie zadowolonych $\mathrm{z}$ ich oferty.

Innym wyzwaniem dla współczesnego konsumenta jest dokonanie wyboru spośród coraz szerszej gamy produktów i usług. Zgodnie z tak zwanym paradoksem Schwarza im większa liczba produktów, tym większe niezdecydowanie konsumenta i szansa, że zrezygnuje on z dokonania zakupu. Przekonanie potencjalnego nabywcy do konkretnej oferty nadal jest wyzwaniem dla współczesnych przedsiębiorstw, które w konsekwencji zaczęły inwestować w systemy rekomendacyjne, sztuczną inteligencję, filtrowanie informacji i aplikacje mobilne, mające zapewnić im przychylność i zadowolenie konsumentów. Można zauważyć, że ci ostatni, opierając się na sugestiach kierowanych do nich programów, coraz częściej popadają w błędne koło decyzyjne i tak zwaną bańkę filtracyjną. Mechanizm jej działania polega na korzystaniu tylko z tych ofert, które pasując do aktualnego profilu nabywcy, zostały przefiltrowane i zaproponowane przez dany algorytm. Tym samym konsument korzystający bezrefleksyjnie z nowych technologii może zawężać swoje horyzonty decyzyjne i stracić szansę na nowe doświadczenia.

$\mathrm{Z}$ jednej strony rewolucja cyfrowa zwiększyła możliwości informacyjne i planistyczne konsumentów, umożliwiając im podejmowanie decyzji na podstawie wielu zróżnicowanych zmiennych, z drugiej zaś nieetyczne praktyki części przedsiębiorstw oraz bezrefleksyjność samych konsumentów odnośnie do zalet i wad nowych technologii sprawiły, że zamykają się oni we własnym imaginarium, nadal dokonując zakupów, z których nie czerpią pełnego zadowolenia. 


\section{Bibliografia}

Akerkar R., Artificial Intelligence for Business, Harvard 2018.

Brennan K., The managed teacher, emotional labour, education, and technology, „Educational Insights" 10, 2006, nr 2.

Eeuwen M., Mobile conversational commerce: Messenger chatbots as the next interface between businesses and consumer, https://essay.utwente.nl/71706/1/van\%20Eeuwen_MA_BMS.pdf.

Holzer A., Ondrus J., Mobile application market: A developer's perspective, „Telematics and Informatics" 28, 2011.

Karnani A., McFerran B., Mukhopadhyay A., Leanwashing: A Hidden Factor in the Obesity Crisis, "California Management Review” 56, 2014, nr 4.

Keller K., Nieuniknione. Jak inteligentne technologie zmienią nasza przyszłość, przeł. P. Cypriański, Warszawa 2017.

Konota J., Nieuświadomiona rewolucja cyfrowa. Czy powinniśmy się bać internetu rzeczy?, „Harvard Business Review Polska", https://www.hbrp.pl/b/nieuswiadomiona-rewolucja-cyfrowa-czypowinnismy-sie-bac-internetu-rzeczy/NlNMx88p.

Modliński A., Miękkie i agresywne formy sprzeciwu konsumentów wobec niepożądanych zachowań rynkowych, [w:] Innowacyjne działania w obszarze zarzadzania i marketingu, red. A.A. Wadlewski, A. Modliński, Łódź 2015.

Obermiller C., Spangenberg E.R., Development of a scale to measure consumer skepticism toward advertising, „Journal of Consumer Psychology” 7, 1998, nr 2.

Puschmann K., Alt R., Sharing economy, „Business \& Information Systems Engineering” 58, 2016, nr 1.

Sanchez-Cortes D., Kumano S., Otsuka K., Gatica-Perez D., In the mood for vlog: Multimodal inference in conversational social video, „ACM Transactions on Interactive Intelligent Systems (TiiS) - Special Issue on Behavior Understanding for Arts and Entertainment (part 1 of 2)” 5, 2015, nr 2.

Silvius A.J.G., Silvius C.M., Exploring functionality of mobile applications for project management, „Procedia Computer Science” 64, 2015.

Toffler A., The Third Wave, New York 1980.

\section{Consumer decisions in the era of digital revolution and artificial intelligence: A review of trends}

\section{Summary}

In the era of digital revolution, customers gained access to almost unlimited sources of information about products and services. The article presents selected trends influencing the shape of purchasing decisions and their impact on customer empowerment: mobile applications, chatbots, forums and social media, as well as artificial intelligence and the Internet of things. The author points out both the positive and the negative impact of technological trends on consumer decisions: decrease of trust in companies, overload of information and problems with their verification, too high level of automation. The basic conclusion coming from the analysis is that despite the advent of numerous technological innovations, consumers are closing themselves in filtering bubbles, losing chances of new experiences, as well as confidence in subsequent information sources, which has negative impact on their relationship with both companies and other customers. 